\title{
A case study assessment of socio-economic sustainability and alternative management regimes for state forest plantations in Limpopo Province, South Africa
}

\author{
Precious Munyanduki ${ }^{1}$, Paxie W. Chirwa ${ }^{2}$, Folaranmi D. Babalola ${ }^{2,3}$
}

(1) Department of Forestry, University of Venda, Private bag X5050, 0950, South Africa

(2) Postgraduate Forest Programme, University of Pretoria, Private bag X20, Hatfield, Pretoria, 0028, South Africa

(3) Department of Forest Resources Management, University of Ilorin, 240003, Ilorin, Kwara State, Nigeria

Precious Munyanduki (Corresponding author)

Email: precious.munyanduki@univen.ac.za

Tel: +27159628123

\begin{abstract}
Assessing the socio-economic sustainability of small scale forest plantations provides the basis for monitoring compliance with sustainable forest management principles and prescription of appropriate interventions. Considering that state forest plantations in South Africa have been scheduled for transfer to community-based entities, determination of the potential of alternative forest management types is vital. This study therefore assessed the socio-economic sustainability of current forest management strategies in state forest plantations at Gaba and Rossbach in Limpopo Province of South Africa. It also determined the potential of alternative forest management regimes using perceptions of local communities. Summated rating scales principles were applied by using likert scaling to acquire the perceptions of local communities through scoring of indicators and verifiers. While the local community for Rossbach forest plantation was content with all indicators of socio-economic sustainability, the local community for Gaba was discontent with provision of products and the forest plantation's contribution to their livelihoods. Both communities perceived joint forest management to be the optimal forest management regime across all indicators while expressing total lack of confidence in managing the forest plantations communally. Optimal socio-economic sustainability in the post-transfers era can be achieved through joint decision-making and formalized sharing of responsibilities and benefits between the communities and government.
\end{abstract}

\section{Keywords}

Community forestry, Alternative forest management regimes, Forest plantation, Socioeconomic sustainability, Sustainable forest management

\section{Introduction}

Sustainable Forest Management (SFM) is a dynamic concept that aims to maintain and enhance economic, social and environmental values of forests for the benefit of present and future generations (UN 2008). SFM has become a dominant paradigm worldwide forming the basis of 
modern forest policy and law in most countries (Wolfslehner et al. 2005), South Africa included (Scotcher and Everhard 2001). Apart from the environmental protection and sustainable productivity aspects of SFM, particular attention has also been given to socio-economic sustainability with regard to local communities adjacent to forests. Socio-economic sustainability of forest plantations is essentially characterized by provision of forest goods and services, generation of economic benefits, improvement of local livelihoods, social acceptance and absence of conflicts and other adverse effects (Charnley 2005; Gordon et al. 2013).

Having widely adopted the noble concept of SFM in terms of forest policies and legislation, evaluation and monitoring are therefore of paramount importance in order to ensure actual compliance with the SFM principles. SFM evaluation has been often conducted through audits by certification bodies such as the Forestry Stewardship Council (FSC) and government forestry departments through the use of Criteria and Indicators (C\&I). The C\&I approach has also been used in modern SFM evaluation by independent researchers such as in the assessment of sustainability of community forest management in northern Ethiopia (Balana et al. 2010), assessment of community forestry management activities and alternatives in Nepal (Khadka and Vacik 2012) and in India (Datta and Chatterjee 2012).

The concept of SFM emphasizes provision of benefits to future generations (UN 2008) hence the need for long term forest production and functionality. Restructuring of state-owned forest plantations in South Africa resulted in categorization of the forests into category A, B and C as indicated in Table 1 (DWAF 2004, 2005).

The transfer of category A plantations has been completed whereas transfer of category B and C plantations is still pending, with government now considering shifting responsibility of these plantations from the Department of Agriculture, Forestry and Fisheries (DAFF) to the South African Forestry Company Limited (SAFCOL) (DAFF 2014). In order to ensure long term sustainability of these state forest plantations in South Africa, there is need to determine the optimal forest management regime by assessing potential of alternatives such as the following;

1. Joint forest management (JFM) which is the management of forests through sharing of roles, responsibilities and benefits between government and local communities (Bhattacharya et al. 2010),

2. Company-community partnerships characterized by formal or informal relationships established between companies and local communities (individual or groups) in managing a forest with sharing of benefits and costs (Andrew et al. 2000),

3. Community forestry management whereby the community individually manages the forest plantation either through an elected management committee or through their traditional leadership (Evans 1998),

4. Community user group management which is a variant of community forestry management whereby the forest is owned and managed by a specific group of people from the community (Evans 1998).

The assessment of social acceptance of alternative forest management options has been conducted in Asia e.g. in Nepal (Khadka and Vacik 2012) while little is known in southern Africa. Acquiring perceptions and preferences of the local communities eliminates the potential problems associated with top-down approaches. According to Ham and Theron (1999), earlier woodlot development programmes which were meant to provide wood to local communities 
Table 1 Categorization of state forest plantations in South Africa

\begin{tabular}{|c|c|c|c|c|}
\hline A & High & $\begin{array}{l}\text { Commercial } \\
\text { timber } \\
\text { production }\end{array}$ & $\begin{array}{l}\text { Leased to established } \\
\text { private forestry } \\
\text { companies }\end{array}$ & N/A \\
\hline B & Medium-Low & $\begin{array}{l}\text { Commercial } \\
\text { timber } \\
\text { production }\end{array}$ & $\begin{array}{l}\text { Department of } \\
\text { Agriculture, Forestry } \\
\text { and Fisheries (DAFF) }\end{array}$ & $\begin{array}{l}\text { Local, emerging } \\
\text { investors or } \\
\text { community- } \\
\text { oriented entities }\end{array}$ \\
\hline $\mathrm{C}$ & Low & $\begin{array}{l}\text { Provision of } \\
\text { timber to } \\
\text { local } \\
\text { communities }\end{array}$ & DAFF & $\begin{array}{l}\text { Local } \\
\text { communities or } \\
\text { community- } \\
\text { private } \\
\text { partnerships }\end{array}$ \\
\hline
\end{tabular}

Source: (DWAF 2004, 2005; DAFF 2013, 2014)

failed because of the top-down exclusionary approach that led to lack of participation by the local people. In that regard, the long term sustainability of state forest plantations after transfer of their ownership and management is also vulnerable to failure if the perceptions of the potential beneficiaries, the local communities, are not determined.

The study aimed at evaluating the performance of Gaba and Rossbach state forest plantations against socio-economic indicators of SFM and to analyze community perceptions on the potential of alternative forest management regimes towards achievement of socio-economic sustainability. The expected output of the study was twofold. First, it was expected to provide up-to-date information on the status of compliance with SFM principles relating to socioeconomic impacts of small scale forest plantations on rural communities thereby providing a basis for prescription of appropriate interventions. Secondly, the study was meant to identify the most suitable and appropriate alternative forest management regime as perceived by the local communities. Preferences of the local communities will inform policy-makers on how to develop new and/or modify existing management regimes in order to accommodate the local communities thereby eliminating the potential problems associated with top-down approaches. 


\section{Materials and methods}

Study area

The study was conducted at Gaba and Rossbach forest plantations which are in Thulamela and Makhado local municipalities within the Vhembe District of Limpopo Province in South Africa (Figure 1).

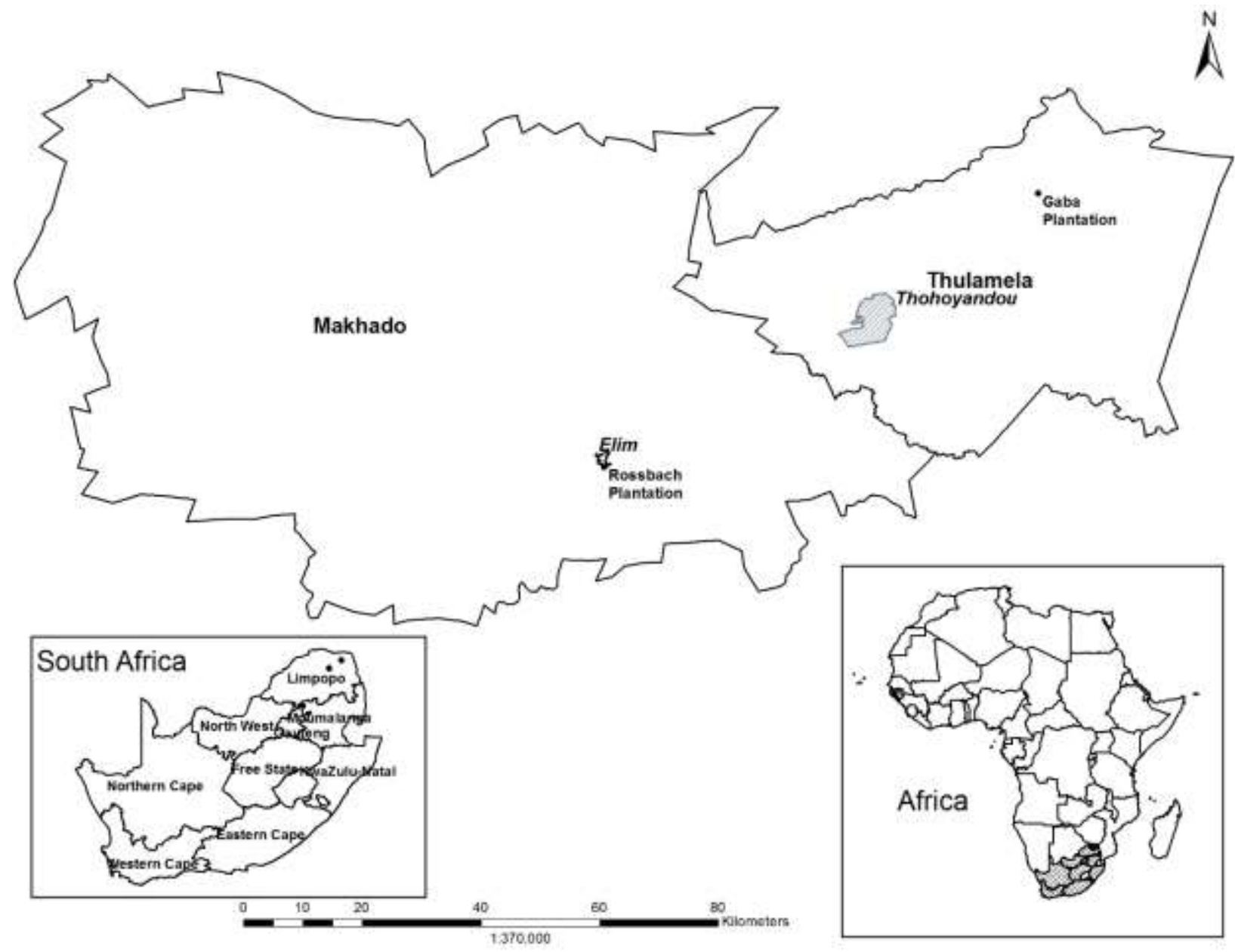

Fig. 1 Map showing location of study sites

Gaba and Rossbach plantations were purposively selected as cases to represent category $\mathrm{C}$ and category B state plantations in South Africa, respectively. As shown in table 2, the biophysical characteristics of the two plantations typify the categorization conducted by DAFF as part of its forestry restructuring process (Table 1). For instance, due to its lack of accessibility, the economic viability of Gaba plantation was categorized as low thus considered to be more valuable under ownership and utilization by the local community. 
Table 2 Biophysical characteristics of Gaba and Rossbach plantations

\begin{tabular}{|c|c|c|c|}
\hline \multicolumn{2}{|l|}{ Plantation } & Gaba & Rossbach \\
\hline \multicolumn{2}{|l|}{ Category } & $\mathrm{C}$ & B \\
\hline \multicolumn{2}{|l|}{ Geographic location } & $\begin{array}{l}22^{\circ} 46^{\prime} 60^{\prime \prime} \text { South, } \\
30^{\circ} 43^{\prime} 0^{\prime \prime} \text { East }\end{array}$ & $\begin{array}{l}23^{\circ} 11^{\prime} 52.9^{\prime \prime} \text { South } 30^{\circ} \\
03^{\prime} 33.3^{\prime \prime} \text { East }\end{array}$ \\
\hline Estimated area in hectares & $\begin{array}{l}\text { Planted } \\
\text { Unplanted } \\
\text { Total }\end{array}$ & $\begin{array}{l}300 \mathrm{ha} \\
1000 \mathrm{ha} \\
1300 \mathrm{ha}\end{array}$ & $\begin{array}{l}\text { 92.27ha } \\
20.71 \mathrm{ha} \\
112.98 \mathrm{ha}\end{array}$ \\
\hline \multicolumn{2}{|l|}{ Species planted } & Pines and Eucalypts & Eucalypts \\
\hline \multicolumn{2}{|c|}{ Distance from nearest town/township } & $40 \mathrm{~km}$ & $7 \mathrm{~km}$ \\
\hline \multicolumn{2}{|l|}{ Surrounding village (s) } & Gaba & Njhakanjhaka \\
\hline \multicolumn{2}{|c|}{$\begin{array}{l}\text { Sub-village closest to plantation } \\
\text { (administration office) }\end{array}$} & Tshikudini & Magangeni \\
\hline
\end{tabular}

Since this study was based on perceptions of local communities, the actual study populations were considered as the sub-villages closest to the plantations. This was meant to represent the most conservative form of a "local community" for the plantations according to the definition given by the FSC. According to the FSC (2012), a local community is a community of any size that is within or close to the management unit such that it may have a significant impact on the economy or the environmental values of the management unit. Tshikudini and Magangeni subvillages were therefore purposively selected as the local communities for Gaba and Rossbach forest plantations respectively by virtue of being closest to the forest plantations. The use of entire sub-villages as study populations was also motivated by the fact that members share the same resources and are a coherent social group that falls under the same traditional authority, the headman. The concept of "local community" in this study therefore carries a particular definition as informed by sustainable forest management concept as well as the logical characterization of a community.

Tshikudini sub-village consists of about 177 households within Gaba village whereas Magangeni sub-village consists of about 400 households within Njhakanjhaka village. These two communities are both characterized by very high levels of unemployment such that the majority of community members depend on social grants provided by the government. Other livelihood strategies are subsistent production of crops, particularly maize, as well as cattle and goat production. The low income nature of these communities is exhibited by the poor living conditions. At Gaba, about $16 \%$ of the Gaba villagers do not have any toilets, $71 \%$ have pit toilets without ventilation and only $4 \%$ have flush toilets (SSA 2014). At Njhakanhjaka, 44\% of the villagers do not have access to piped water and 58\% have pit toilets without ventilation (SSA 
2014). Although both villages are electrified (>90\%), 78\% and 38\% of the villagers of Gaba and Njhjakanjhaka respectively, still use firewood for cooking toilets (SSA 2014).

\section{Research methods}

Focus group discussion

A focus group discussion was conducted with three forestry officials in the Department of Agriculture, Forestry and Fisheries (DAFF) responsible for managing the selected forest plantations. Composition of the focus group was made up of only the forestry officials to facilitate homogeneity of the group (Sarantakos 1998). The focus group discussion was meant to collect information on functionality of the forest plantations and deliberate on relevant socioeconomic issues in order to adequately and accurately define indicators (Sarantakos 1998). The information gathered included mechanisms used for interaction with local communities particularly with regard to access and use arrangements, provision of forest plantation products, employment and income generating activities.

\section{Household questionnaire}

Listing and enumeration of households in-field (Devereux 1992; Bailey 1994; Barber et al. 1997) was done in order to construct sampling frame for random sampling. A sketch map was created by driving through all roads within the sub-villages and assigning a unique reference number to each household. Simple random sampling was used to select respondent households for the study, to maximize representativeness (Nachmias and Frankfort-Nachmias 1992; Babbie and Mouton 2001; Monnette et al. 2014). The lottery method (Sarantakos, 1998) was then used to randomly select the participant households which were located and identified using the sketch maps developed earlier. At Tshikudini, 50 out of the 177 households were selected whereas 102 out of 407 households were selected at Magangeni. According to Sarantakos (1998), sample size and representativeness differs with homogeneity of population, type of research and availability of resources, with most qualitative researchers being content with minimum sample sizes of 30100. Due to the confinement of the households in small geographical constructs and common use of the plantations in their vicinity, sample sizes of 50 and 102 were deemed representative enough to answer the research questions and objectives.

Owing to the low literacy levels in South Africa, the questionnaire was interpreted into Tshivenda and Xitsonga which are the local languages spoken in the two study sites (Babbie and Mouton 2001). Depending on preference of a particular respondent, questionnaires were administered in the local languages to most of the respondents while a few were administered in English. The questionnaire covered general socio-economic profile of the respondent; communities' use of forest products and involvement in forest protection and income-generating activities. In addition, the questionnaire examined verifiers for socio-economic sustainability of current forest management and indicators for assessing potential performance of alternative forest management regimes (i.e. JFM, company-community partnerships, community forestry management and community user group). 
Table 3 Final set of indicators and verifiers used for evaluating socio-economic sustainability and potential of alternative management regimes for Gaba and Rossbach plantations

\begin{tabular}{|c|c|}
\hline Indicator & Verifier \\
\hline \multirow{5}{*}{$\begin{array}{l}\text { Provision of wood } \\
\text { products and } \\
\text { livelihoods } \\
\text { improvement }\end{array}$} & Wood products are obtained from the plantation \\
\hline & Plantation products suffice household needs \\
\hline & Plantation products suffice needs for income-generation \\
\hline & The plantation and its products contribute to household income. \\
\hline & The plantation and its products improve livelihoods \\
\hline \multirow{5}{*}{$\begin{array}{l}\text { Prioritization of } \\
\text { communities to } \\
\text { business and } \\
\text { employment } \\
\text { opportunities }\end{array}$} & Local people are informed of income-generating opportunities \\
\hline & Local community members are given preference for business \\
\hline & opportunities. \\
\hline & Local people are informed of employment opportunities \\
\hline & Local people are given preference to employment opportunities \\
\hline \multirow{5}{*}{$\begin{array}{l}\text { Facilitation of local } \\
\text { communities' } \\
\text { participation }\end{array}$} & Consultation on plantation management issues. \\
\hline & Consultation on access and use of plantation products. \\
\hline & Consultation on protection of the plantation \\
\hline & $\begin{array}{l}\text { Consultation on employment and entrepreneurial opportunities in the } \\
\text { plantation. }\end{array}$ \\
\hline & $\begin{array}{l}\text { There is an effective communication between plantation management and } \\
\text { local communities. }\end{array}$ \\
\hline \multirow{5}{*}{$\begin{array}{l}\text { Participation in } \\
\text { plantation activities }\end{array}$} & Local communities influence decisions on plantation management. \\
\hline & Assistance in protection against fire damage and illegal harvesting. \\
\hline & $\begin{array}{l}\text { Local communities are aware of employment and entrepreneurial } \\
\text { opportunities }\end{array}$ \\
\hline & Utilization of wood from plantation as opposed to natural forest. \\
\hline & The outcomes of local communities' consultations are implemented. \\
\hline \multirow{10}{*}{$\begin{array}{l}\text { Knowledge, respect } \\
\text { and fairness of } \\
\text { plantation } \\
\text { ownership, } \\
\text { management and } \\
\text { use arrangements }\end{array}$} & Ownership of plantation is known and understood \\
\hline & Access and use regulations are known, understood and respected. \\
\hline & Standard of general plantation management and service provision is \\
\hline & satisfactory \\
\hline & Ownership arrangements for the plantation are fair. \\
\hline & Access and use arrangements for plantation products are fair. \\
\hline & $\begin{array}{l}\text { There is fairness and transparency in plantation related business } \\
\text { opportunities. }\end{array}$ \\
\hline & Plantation employment opportunities are fairly availed \\
\hline & $\begin{array}{l}\text { There are no conflicts between local communities and DAFF regarding } \\
\text { ownership of the plantation. }\end{array}$ \\
\hline & $\begin{array}{l}\text { There are no conflicts between local communities and DAFF regarding } \\
\text { access and use of the plantation. }\end{array}$ \\
\hline \multirow{4}{*}{$\begin{array}{l}\text { Effective } \\
\text { management and } \\
\text { resolution of } \\
\text { conflicts and } \\
\text { grievances }\end{array}$} & Effective mechanisms for expression of grievances exist. \\
\hline & Grievances from local users are timeously attended to and resolved. \\
\hline & There are conflict resolution mechanisms between local communities \\
\hline & Conflicts are respectfully handled and peacefully resolved. \\
\hline
\end{tabular}


Development of relevant indicators and verifiers

We developed a preliminary set of C\&I using the local provisional forest management unit C\&I set (DWAF 2008), the Center for International Forestry Research (CIFOR) C\&I generic template (CIFOR 1999), FSC principles and criteria (FSC 2012) and International Tropical Timber Organization (ITTO) revised criteria and indicators for sustainable management of tropical forests (ITTO 2005). The likert scale was then used for assessment of verifiers and indicators followed by four response alternatives [1 (strongly disagree); 2 (disagree); 3 (agree) and 4 (strongly agree)] to measure respondents' attitudes (Nachmias and Frankfort-Nachmias 1992; Monnette et al. 2014). Cronbach's Alpha was then used to test for reliability of the likert scale items (verifiers) in order to identify and exclude those which are internally inconsistent (Nachmias and Frankfort-Nachmias 1992; Sarantakos 1998; Monnette et al. 2014). Groups of verifiers and indicators with a minimum Cronbach's alpha value of 0.70 were accepted and retained (See-Nachmias and Frankfort-Nachmias 1992). The final C\&I set for both study areas were composed of six indicators and 32 verifiers (Table 3 ).

\section{Data analysis}

The internal consistency which was confirmed by reliability testing allowed for application of summated rating principles whereby the indicator scores were calculated by summing up the responses from all verifiers of each indicator (Desselle 2005; Martinez-Martin 2010; Monnette et al. 2014) as represented by Equation 1. The indicator scores were then standardized into a percentage value (Martinez-Martin 2010) based on highest possible performance score (See equation 1).

$S_{i}=\frac{\sum_{i=1}^{n} v_{i}}{p n_{i}} \times 100$

Where $S_{i}$ denotes the total performance score of indicator $i$ in percent, $v_{i}$ denotes likert score of verifiers of indicator $i, n_{i}$ denotes total number of verifiers for indicator $i, p$ denotes the highest possible score of the likert response format. The confirmation of internal consistency of the verifiers within their respective indicators allowed for summation of the scores of verifiers to give total scores for each indicator. The conversion of the total indicator scores into percentage values then expresses the perceptions of the respondents as indicator performance scores $\left(S_{i}\right)$ whereby the highest performance score would be $100 \%$ and the lowest would be $25 \%$.

Following the summated rating scales concept (Desselle 2005; Martinez-Martin 2010; Monnette et al. 2014), overall potential socio-economic sustainability of each alternative forest management regime was computed by summation of responses of all indicators. Friedman's test was then used to test for differences among the potential performance scores of alternative forest management regimes (Rohatgi 1984; Mattson 1986). It was also used to rank the respondents' scores for the alternative forest management regimes thereby determining the regime with the highest potential. Such ranking analysis was adopted from Fakayode et al. (2012) who used Kruskal-Wallis ANOVA by ranks to assess farmers' perceptions on major sources of risk in fruit and vegetable farming while simultaneously ranking the sources. The Friedman's test equation 
for estimating the ranks for the scores of the four alternative forest management regimes is shown in equation 2.

$F=\frac{12}{b k(k+1)} \sum_{j=1}^{k} R_{j}^{2}-3 b(k+1)$

Where $b$ denotes the number of scores in a group and $k$ denotes the number of groups (Rohatgi 1984; Mattson 1986). Statistical tests were conducted using SPSS version 22 using a significance level of 0.05 .

Frequencies were computed for summarizing the nominal variables (Cramer 1998) regarding respondents' demographic profiles and participation of respondents in forestry activities. The Chi square goodness of fit test was used to test for differences between observed and expected frequencies (Nachmias and Frankfort-Nachmias 1992; Bless and Kathuria 1993; Cramer 1998; Sarantakos 1998) among categories of nominal variables for participation of communities in forestry activities. Chi square test of association was used to test for association between participation variables and communities using cross-tabulation (Cramer 1998). Where the expected frequencies were too small, some response categories were combined. Mann Whitney U test was used to test for differences (Nachmias and Frankfort-Nachmias 1992; Bless and Kathuria 1993; Cramer 1998; Sarantakos 1998) between the two communities regarding indicator scores as well as total scores of alternative forest management regimes.

\section{Results}

Demographic information of respondents

Over $50 \%$ of respondents in both Tshikudini and Magangeni communities had attended secondary school followed by between $20-30 \%$ with primary education. Tertiary education was attended by the least number of respondents accounting for only $6 \%$ in both communities. High unemployment levels were evident for both Magangeni community (82.2\%) and Tshikudini community (92\%). The majority (64.6\%) of the respondents in Tshikudini had total household monthly incomes lower than R452 (US\$ 37.52) whereas in Magangeni, most respondents (46.9\%) had household incomes between R453-R2000 (US\$ 37.60- US\$ 166.00) ${ }^{1}$.

\section{Participation of local communities in forestry activities}

Questions relating to participation in forest-related activities were only directed to respondents who were aware of the functioning of forest plantations within their respective villages. It was assumed that respondents who indicated that they did not know about the forest plantations did not participate in any forest plantation-related activities and therefore would not provide valid responses in that regard. At Tshikudini, 96\% $(n=48)$ of the respondents were aware of the access and use arrangements of Gaba forest plantation whereas $75.5 \%(n=77)$ were aware of Rossbach forest plantation at Magangeni.

\footnotetext{
${ }^{1}$ The South African Rand to US\$ exchange rate used was 0.083 on 14 July 2015
} 
The majority of respondents in both communities (84-92\%) actively participated in protection of the forest plantations. A Chi-square goodness of fit test showed that the differences in frequencies of participants compared to non-participants were significant for both Tshikudini $\left(\chi^{2}=33.333, p=0.000\right)$ and Magangeni $\left(\chi^{2}=34.680, p=0.000\right)$ communities. As presented in Table 4 , the most common forest protection activities were fire control for Magangeni $(77.8 \%)$ and reporting fire incidences for Tshikudini (72.7\%). However, reporting of illegal activities was undertaken by the least number of respondents at Tshikudini whereas at Magangeni, reporting fire incidences was the least practiced activity (Table 4).

Table 4 Participation in plantation forest protection and collection of wood by Magangeni and Tshikudini communities

\begin{tabular}{lll}
\hline Activity & \multicolumn{2}{c}{ Frequency (\% respondents) } \\
\cline { 2 - 3 } & Magangeni & Tshikudini \\
\hline Forest protection & $N=75$ & $N=47$ \\
Fire control & 77.8 & 36.4 \\
Reporting fire incidences & 9.5 & 72.7 \\
Reporting illegal harvesting & 12.7 & 4.5 \\
Fire control and reporting fire incidences & 0.0 & 11.4 \\
Reporting fire incidences and illegal harvesting & 0.0 & 2.3 \\
& & \\
\hline Collection of firewood & $N=75$ & $N=46$ \\
Plantation & 56.0 & 13.0 \\
Natural forest & 41.3 & 84.8 \\
Formal shops/informal traders & 2.7 & 2.2 \\
& & \\
Chi-square & 34.160 & 55.609 \\
Degrees of freedom & 2 & 2 \\
Asymp. Sig & 0.000 & 0.000 \\
& & \\
\hline Collection of poles & $N=71$ & $N=47$ \\
Plantation & 60.6 & 31.9 \\
Natural forest & 31.0 & 46.8 \\
Formal shops/informal traders & 8.5 & 21.3 \\
& & \\
Chi-square & 29.099 & 4.638 \\
Degrees of freedom & 2 & 2 \\
Asymp. Sig & 0.000 & 0.098 \\
\hline
\end{tabular}

During a focus group discussion with government forestry officials, it was emphasized that category $\mathrm{B}$ and $\mathrm{C}$ forest plantations under their management are mostly situated in impoverished rural areas; thus forming an essential source of wood products and income, in line with 
government's policies. The forest plantations provide, among others, firewood and poles to local communities through collection of headloads for free while larger quantities are sold at affordable prices. The majority of the community at Tshikudini $(84.8 \%)$ collected their firewood from the natural forest whereas only $13.0 \%$ collected from the forest plantation (Table 4 ). At Magangeni, $56.0 \%$ collected their firewood from the forest plantation compared to $41.0 \%$ who collected from the natural forest and $2.7 \%$ that purchase firewood from formal shops and informal traders. There were highly significant differences among the different sources of firewood used by both Tshikudini community $\left(\chi^{2}=55.609, \mathrm{p}=0.000\right)$ and Magangeni community $\left(\chi^{2}=34.160, \mathrm{p}=0.000\right)$. There was a significant association between local community and source of firewood used $\left(\chi^{2}=21.984, \mathrm{p}=0.000\right)$. As also indicated in Table 4 , the majority of respondents in Tshikudini community (46.8\%) collected poles for household use from the natural forest whereas only $31.9 \%$ obtained from the forest plantation. However, the majority of respondents in Magangeni community $(60.6 \%)$ obtained their poles from the forest plantation whereas only $31.0 \%$ collected from the natural forest. Differences in source of poles were thus only significant for the Magangeni community $\left(\chi^{2}=29.099, \mathrm{p}=0.000\right)$. There was a significant association between the local community and source of poles used $\left(\chi^{2}=10.052, p=0.000\right)$.

With respect to cash savings due to utilization of forest plantation products, a Chi-square goodness of fit test showed that there were significant differences in categories of amount of cash saved in both Tshikudini $\left(\chi^{2}=46.600, p=0.000\right)$ and Magangeni communities $\left(\chi^{2}=40.743\right.$, $\mathrm{p}=0.000$ ). There was also a significant association between a particular local community and the amount of cash saved by respondents $\left(\chi^{2}=20.549, \mathrm{p}=0.000\right)$. The majority of respondents at Tshikudini (82.9\%) saved monthly income of less than R100 (US\$8.30) whereas at Magangeni, 48.6\% saved between R100-R200 (US\$8.30-16.60) per month. At Magangeni, some respondents (2.9\%) managed to save amounts greater than R300 (US\$24.90) monthly whereas at Tshikudini, the highest amounts saved were between R201-R300 (US\$16.68-24.90). The Magangeni community saved higher amounts of money than the Tshikudini community because more people obtained higher quantities of wood products from Rossbach forest plantation.

Forestry officials indicated that local communities are prioritized for employment and participation in income-generating activities such as contracts for silvicultural operations. In addition, some local people and outsiders buy firewood and poles in bulk from the forest plantations and resell them for profit while others put beehives within the forests for honey production. However, the number of people participating in such activities was very low $(<10 \%)$ in both communities. A Chi-square goodness of fit test revealed that the differences in frequencies of participants compared to non-participants were significant for both Tshikudini $\left(\chi^{2}=43.085, \mathrm{p}=0.000\right)$ and Magangeni $\left(\chi^{2}=51.946, \mathrm{p}=0.000\right)$ communities. Only a few of the respondents were employed in the forest plantations (2-3\%). At Magangeni, 5.6\% of the respondents also participated in firewood/pole retail and honey production.

Perceptions of local communities on current socio-economic sustainability

Using equation 1, the perceptions of respondents in Magangeni community on the socioeconomic indicators resulted in performance scores of all the indicators of between $57.5 \%$ and $65.2 \%$ (Table 5). Perceptions of respondents at Tshikudini resulted in indicator performance scores of between $36.9 \%$ and $59.5 \%$. Provision of wood products and improvement of 
livelihoods (Indicator 1) from Gaba forest plantation was poor (36.9\%) as compared to Rossbach $(62.0 \%)$ resulting in a highly significant difference in performance between the two forest plantations $(\mathrm{U}=226.000, \mathrm{p}=0.000)$. Based on the perceptions of the respondents, the difference between the two forest plantations regarding level of participation of the local communities in forestry activities (Indicator 4 ) was also highly significant $(U=551.500, p=0.000)$. Respondents in both communities were contend with the level to which the forestry officials engage them in matters pertaining to the forest plantations. The forestry officials indicated that they engage with the communities and disseminate information using a variety of methods such as meetings, notices in public places, sending notifications to traditional authorities, among others.

Table 5 Indicator performance scores for Gaba and Rossbach plantations calculated using Equation 1.

\begin{tabular}{llll}
\hline \multicolumn{2}{l}{ Indicator } & \multicolumn{2}{c}{ Indicator performance (\%) } \\
\cline { 3 - 3 } & & $\begin{array}{l}\text { Rossbach } \\
\text { (Magangeni) }\end{array}$ & $\begin{array}{l}\text { Gaba } \\
\text { (Tshikudini) }\end{array}$ \\
\hline 1. & $\begin{array}{l}\text { Provision of wood products and livelihoods } \\
\text { improvement }\end{array}$ & $62.0^{*}$ & $36.9^{*}$ \\
2. & $\begin{array}{l}\text { Prioritization of local people to business and } \\
\text { employment opportunities }\end{array}$ & 57.5 & 59.0 \\
3. $\begin{array}{l}\text { Facilitation of local communities' participation } \\
\text { 4. Participation in plantation activities }\end{array}$ & 57.9 & 59.5 \\
5. $\begin{array}{l}\text { Knowledge, respect and fairness of plantation } \\
\text { ownership, access and use arrangements }\end{array}$ & $65.2^{*}$ & $53.7^{*}$ \\
6. $\quad$ Management and resolution of conflicts and grievances & 60.3 & 55.5 \\
\hline
\end{tabular}

Significant differences between the two communities

Perceptions of local communities on potential of alternative forest management regimes

The majority of respondents from both communities expected joint forest management regime to achieve optimal performance across all indicators of socio-economic sustainability (Table 6). In contrast to Magangeni, the majority of Tshikudini community members perceived communityuser-group and company-community partnerships to also have some potential in facilitating their participation in forestry activities and prioritizing them to income-generating opportunities. These forest management regimes were also expected to ensure that forest plantation management and use arrangements are fair, understood and respected thereby increasing provision of wood products and improvement of livelihoods. Community-user-group forest management regime was also expected to be able to facilitate effective management of conflicts and grievances. 
Table 6 Mode of indicators for alternative management regimes

\begin{tabular}{lllllll}
\hline \multirow{2}{*}{ Indicator } & Local & \multicolumn{4}{c}{ Mode $^{\mathrm{a}}$} \\
\cline { 3 - 6 } & & community & CFM & CUG & JFM & CCP \\
\hline 1. & Provision of wood products and livelihoods & Magangeni & 2 & 2 & 4 & 2 \\
& improvement & Tshikudini & 2 & 3 & 3 & 3 \\
2. & Prioritization of local people to business and & Magangeni & 2 & 2 & 4 & 2 \\
& employment opportunities & Tshikudini & 2 & 3 & 3 & 3 \\
3. & Facilitation of local communities' participation & Magangeni & 2 & 2 & 4 & 2 \\
& & Tshikudini & 2 & 3 & 3 & 2 \\
4. & Participation in plantation activities & Magangeni & 2 & 2 & 3 & 2 \\
& & Tshikudini & 2 & 2 & 3 & 2 \\
5. & Knowledge, respect and fairness of plantation & Magangeni & 2 & 2 & 4 & 2 \\
& ownership, access and use arrangements & Tshikudini & 2 & 3 & 3 & 3 \\
6. & Management and resolution of conflicts and & Magangeni & 2 & 2 & 4 & 2 \\
& grievances & Tshikudini & 2 & 3 & 3 & 2
\end{tabular}

\footnotetext{
${ }^{a}$ Most frequent response, where 1 is "strongly disagree", 2 "disagree", 3 "agree", 4 "strongly agree"; CFM "Community forestry management", CUG "Community-user-group", JFM "Joint forest management", CCP "Company-community partnership
}

The Friedman's test revealed that there were highly significant differences among the overall potential performance scores of the four alternative forest management regimes for both Tshikudini $\left(\chi^{2}=32.079, \mathrm{p}=0.000\right)$ and Magangeni $\left(\chi^{2}=53.789, \mathrm{p}=0.000\right)$ communities. Through ranking analysis, joint forest management was ranked first implying that both communities perceived it to have the highest potential to achieve socio-economic sustainability of the two forest plantations (Table 7). Community forestry management and community-user-group

Table 7 Ranking analysis for alternative management regimes using Friedman's test

\begin{tabular}{|c|c|c|c|c|}
\hline \multirow[t]{2}{*}{ Alternative management regime } & \multicolumn{2}{|c|}{ Tshikudini $(\mathrm{n}=41)$} & \multicolumn{2}{|c|}{ Magangeni $(n=51)$} \\
\hline & Mean rank & Rank $^{\mathrm{a}}$ & Mean rank & Rank $^{\mathrm{a}}$ \\
\hline Community forestry management & 1.87 & 4 & 2.1 & 3 \\
\hline Community-user-group & $2.63^{*}$ & 2 & $1.95^{*}$ & 4 \\
\hline Joint forest management & $3.3^{*}$ & 1 & $3.56^{*}$ & 1 \\
\hline Company-community partnership & 2.2 & 3 & 2.34 & 2 \\
\hline Chi-square & 32.079 & & 53.789 & \\
\hline Degrees of freedom & 3 & & 3 & \\
\hline Asymp. Sig & 0.000 & & 0.000 & \\
\hline
\end{tabular}


regimes were ranked fourth implying that they were perceived to have the least potential by the two communities. Mann Whitney U test revealed that community-user-group was allocated significantly higher scores $(\mathrm{U}=609.000 .000, \mathrm{p}=0.000)$ by the Tshikudini community compared to the Magangeni community who allocated higher scores to joint forest management ( $\mathrm{U}$ $=564.000, \mathrm{p}=0.000)$.

\section{Discussion}

Utilization of forest plantation products

Gaba and Rossbach forest plantations provided firewood and poles to Tshikudini and Magangeni communities in varying degrees. Almost all the respondents in Magangeni community obtained their firewood and poles from the forest plantation hence they perceived Rossbach forest plantation to be providing them with sufficient wood products. This finding is in line with that of Ham (2000b) and Cocks et al. (2000) in state forest plantations in the Eastern Cape where considerable amounts of firewood and poles were being obtained by locals for subsistent use. In contrast, the majority of respondents in Tshikudini community neither collects firewood nor buys poles from the forest plantation. This low utilization of Gaba forest plantation as compared to Rossbach can be attributed to the long distance of the forest plantation from the community, poor access as well as availability of indigenous trees close to the community. Similarly, studies in the Eastern Cape revealed that lack of utilization of forest plantation products was due to preference for indigenous species (Cocks et al. 2000; Gugushe et al. 2008), long distance from the forest plantation, proximity of the more preferred indigenous trees and poor accessibility (Ham 2000b). Utilization of products from the two forest plantations resulted in cash savings greater than R300 (US\$24.90) per month. This is a significant amount considering the unemployment levels and low income nature of these communities. Similarly, other authors have also reported generation of cash savings from use of forest goods and services which can then be used to finance other livelihood requirements (Shackleton and Shackleton 2004; Ham and Chirwa 2008).

Participation of local communities in income generating activities

Remuneration from employment is potentially a significant form of income generation for local communities surrounding forest plantations (Charnely 2005; Mayers 2006). In this case, although only a few respondents were employed in the forest plantations, there was a general acknowledgement by both communities regarding employment opportunities offered by the forest plantations (Table 5). The positive sentiments expressed by the two local communities are in line with the report by Ham (2000a) that state forest plantations in the Eastern Cape were actually overstaffed in comparison to private forest companies. However, it has also been widely reported that forestry employment opportunities tend to benefit outsiders in comparison to local communities in regions such as Australia and Southeast Asia (Hall 2003; Schirmer and Tonts 2003). Despite this shortfall, some countries such as New Zealand have been recognized for empowering local communities through forestry employment (Charnley 2005). Forest plantations on their own are bound to create only limited employment opportunities unless they are in combination with timber processing activities. Furthermore, it was reported that eucalypts, 
unlike other species such as pines, offer less employment opportunities because of limited tending operations (Charnley 2005). In this case, the ability of the eucalypts to regenerate by coppice implies that these government forest plantations do not need labor for replanting at the end of each rotation.

In both Magangeni and Tshikudini communities, there were only a few respondents who participated in other forest-related income generating activities despite acknowledgement of the existence of such opportunities. This could be attributed to poor access to markets beyond the community level and lack of capital. According to Rogerson (2001), viability and success of any enterprise is largely determined by proximity to sufficient markets. Optimization of economic returns thus requires supplying commercial markets which implies the need for capital investment to fund establishment of processing mills for value addition and transport logistics, among others. However, just like other rural communities in South Africa, Tshikudini and Magangeni communities are poor and therefore not considered for business loans. Similarly, Cocks et al. (2000) reported that communities around Manubi woodlot in the Eastern Cape did not participate in pole retail because of the lack of capital despite the low prices set for the poles. Notwithstanding, the few respondents who participated in forest plantation related income generating ventures indicated that the incomes contributed significantly to increasing their purchasing ability for household commodities, better housing, education and access to clean water.

\section{Social sustainability of forest plantations}

The two communities were consulted on matters regarding forest plantation management such as access and use rights and forest protection hence their assistance in protecting the forests as well as absence of conflicts (Table 5). According to Gordon et al. (2013), social sustainability which is brought about through community engagement, is now an essential component of every organization including forestry industries, in order to incorporate stakeholder concerns in its functions. Effective community engagement ensures that forest management in-cooperates the needs and aspirations of local communities thereby increasing the positive impacts while avoiding, reducing and remediating the negatives. Dare et al. (2012) asserted that community engagement provides an opportunity to acquire, process and address concerns of local communities thereby avoiding conflicts while ensuring overall long-term sustainability of forest plantation management.

\section{Potential of alternative forest management regimes}

Respondents at both Tshikudini and Magangeni communities felt that management of the forest plantation by the community through traditional authorities does not have any potential in achieving socio-economic sustainability. Similar sentiments have been expressed for community management of indigenous forests in Limpopo and Eastern Cape Provinces of South Africa (Sikhitha 1999; Obiri and Lawes 2002; Robertson and Lawes 2005). From the current study, the lack of confidence of the people in the community forestry management regime was attributed to the decline in effectiveness of traditional authority in modern South Africa. Earlier studies in the 
Eastern Cape also found that local communities did not feel confident to manage forest plantations themselves because of lack of experience and community organization and possibility of uncontrolled harvesting (Andrew et al. 2000). According to Thoms (2008), the success or failure of forest management by communities primarily depends on social stratification and prior collective action experience within the communities. Behera (2009) further presented the demanding nature of community forestry management based on its need for homogeneity of the community, small size of the community, resource scarcity, among others. In fact, Oses-Eraso and Viladrich-Grau (2007), reported that collective management of any resource without over-exploitation has not yet been efficiently justified by any economic theory.

Community-user-group forest management regime is somewhat, a more organized variant of community forestry management whereby only a specific group of individuals would own and manage the forest plantation thereby facilitating homogeneity and accountability. As such, the Tshikudini community perceived this regime to have some potential in achieving socioeconomic sustainability. However, the Magangeni community still did not confide in this form of forest management because of similar weaknesses of "entire" community management i.e. communal resource protection rules and other forest regulatory rules developed by the user group and/or traditional authorities would not be complied with by the user group members and/or the other villagers. Community-user-group forest management offers a challenge in developing socially acceptable criteria for appointing beneficiaries as well as a justification for exclusion of the others hence its vulnerability to conflicts and undesirable disruption of community cohesion. Previous experience with community group-managed Masakhona woodlot in South Africa supports the sentiments of the Magangeni community as reported by Evans (1998) that Masakhona was a site of emerging conflicts caused by discontent with benefit sharing arrangements. Similarly, in Nepal, some community forest user groups have been reported to have worsened the plight of the poor through restrictions on products (Pokharel 2012) due to the inherent lack of consultation and capacity of the poor to express their opinions and/or participate (Thoms 2008).

Both Tshikudini and Magangeni communities perceived that company-community partnerships have some potential as they would prioritize the communities to employment and business opportunities while also providing reasonable access and use arrangements. Partnerships between private companies and individual growers have been reported as successful in South Africa with individuals involved in out-grower schemes earning about US\$ 130 per year (Mayers 2006). However, Andrew et al. (2000) reported unsuccessful partnerships between companies and communities.

Joint forest management (JFM) between the communities and government was perceived as the forest plantation management with the highest potential across all indicators of socio-economic sustainability and in both communities (Table 6 and 7). This corroborates earlier findings where communities have shown preference for this form of management in both indigenous and forest plantations in South Africa (Andrew et al. 2000; Robertson and Lawes 2005). The ultimate strength of this forest management regime is vested in its ability to empower communities through government's technical, financial and regulatory support. This is evidenced by the success of earlier 'community' projects in South Africa where government provided technical and financial support to communities for establishment of forest plantations (Howard et al. 2005). In other countries, different models of JFM have been implemented with success in forest 
protection and improvement of local livelihoods e.g. in India, Bangladesh and Indonesia (Tewari and Isemonger 1998; Muhammed et al. 2008; Bhattacharya et al. 2010; Djamhuri 2012).

\section{Conclusions}

Generally, communities adjacent to both forest plantations expressed positive perceptions regarding the entire socio-economic performance aspects of the forest plantations except for discontent over provision of wood products at Gaba forest plantation.

The study showed that those involved in management of the forest plantations effectively consulted and engaged with the local community regarding access and use arrangements, forest protection, employment and income-generating opportunities. The communities were thus aware of the employment and business opportunities provided by the forest plantations and understood the forest plantation ownership and access and use arrangements and perceived them to be fair. Hence the absence of conflicts and the communities' active participation in protection of the forest plantations against illegal harvesting and fire damage. While Rossbach forest plantation provided wood products to the local community thereby contributing to their livelihoods, limited access resulted in low provision of products from Gaba forest plantation.

The study further showed that joint forest management was perceived by local communities to be the optimal forest plantation management regime that could offer the best socio-economic sustainability for both forest plantations. JFM would enable their participation in forestry activities and improve the livelihoods of local communities while maintaining good relations with government officials. Both communities did not realize any potential in managing the forest plantations communally. Notwithstanding, the local communities felt there was some limited potential of company-community partnerships and community-user-group in management of forest plantations.

Despite the good overall indicator performance for the two forest plantations, there is still need to improve the socio-economic sustainability through increased resource use, community engagement, minimization of conflict and increased contribution to the local economy and livelihoods. The following recommendations can be made:

1. Innovative community engagement methods should be utilized to optimize participation of local communities and resolution of grievances. For instance, attendance of community meetings by forestry officials to reach-out to all community members particularly those that may be completely unaware of the functionality of the forest plantations.

2. Innovative ways of maximizing the contribution of forest plantations to local livelihoods should be considered and researched on. These can be through incorporation or adoption of agroforestry practices and increased capacitation of income generating enterprises such as apicultural practices for honey production. In situations where there is limited provision of firewood from the forest plantations, a formal harvesting regulation through an 'allowable cut' should be introduced where wood can be transported and shared among the community members for household use. 
3. Socio-economic sustainability assessments should be conducted for all forest plantations on a case by case basis since there can be significant variation in the extent to which a particular local community interacts with their respective forest plantation.

4. Further studies should be conducted whereby the potential and feasibility of different detailed models of joint forest management of state forest plantations are explicitly assessed.

\section{Acknowledgements}

Our appreciation goes to the South African Forestry Company Limited (SAFCOL) through the University of Pretoria and the University of Venda for the financial support provided for conducting the study and to DAFF Forestry and Natural Resources Management Limpopo/Mpumalanga staff for allowing us access to the forest plantations as well as the valuable information they provided.

\section{References}

Andrew M, Fabricius C, Timmermans H (2000) An overview of private sector community partnerships in forestry and other natural resources in Eastern Cape. Instruments for sustainable private sector forestry, South Africa series. International Institute for Environment and Development and CSIREnvironmentek, London and Pretoria. http://researchspace.csir.co.za/dspace/bitstream/10204/2493/1/Andrew_2000.pdf. Accessed 10 January 2012

Babbie E, Mouton J (2001) The practice of social research. Oxford University Press, Oxford

Bailey, KD (1994) Methods of social research, $4^{\text {th }}$ edn. The Free Press, New York

Balana BB, Mathijs E, Muys B (2010) Assessing the sustainability of forest management: an application of multi-criteria decision analysis to community forests in northern Ethiopia. J Environ Manage 91(6): 1294-1304

Barber JS, Shivakoti GP, Axinn WG, Gajurel K (1997) Sampling strategies for rural settings: a detailed example from Chitwan valley family study, Nepal. Nepal Population Journal 6 (5): 193-203

Behera B (2009) Explaining the performance of state-community joint forest management in India. Ecol Econ 69(1): 177-185

Bhattacharya P, Pradhan L, Yadar G (2010) Joint forest management in India: experiences of two decades. Resour Conserv Recy 54(8): 469-480

Bless C, Kathuria R (1993) Fundamentals of social statistics: an African perspective. Jutta and Co, Ltd, Cape Town

Charnley S (2005) Industrial plantation forestry: do local communities benefit? J. Sustainable For 21(4): $35-57$

CIFOR (1999) The CIFOR criteria and indicators generic template. The criteria and indicators toolbox series No 2. CIFOR, Jakarta. http://www.cifor.org/publications/pdf_files/CI/toolbox-2c.pdf. Accessed 22 January 2013

Cocks M, Matsiliza B, Fabricius C (2000) Private-sector community forestry partnerships in the Eastern Cape: Longweni woodlot case study. Instruments for sustainable private sector forestry, South Africa series. International Institute for Environment and Development and CSIREnvironmentek, London and Pretoria. 
http://researchspace.csir.co.za/dspace/bitstream/10204/2495/1/Cocks_2000.pdf. Accessed 14 March 2012

Cramer D (1998) Fundamental statistics for social research: step by step calculation and computer techniques using SPSS for Windows. Routledge, London

DAFF (2013) Strategic plan for the Department of Agriculture, Forestry and Fisheries 2013/14-2017/18. DAFF, Pretoria. www.daff.gov.za/doaDev/.../DAFF\%20Strategic\%20Plan\%202013.pdf. Accessed 17 June 2015

DAFF (2014) Annual Report 2013/14. Vote 26. DAFF, Pretoria. www.gov.za/sites/www.gov.za/.../DAFF_Annual_Report_2013-2014.pdf. Accessed 02 July 2015

Dare ML, Vaclay F, Schirmer J (2012) Public participation in commercial environments: critical reflections on community engagement methods used in the Australian plantation forestry industry. Austral For 75(3): 180-191

Datta C, Chatterjee D (2012) Assessment of community-based initiatives in sustainable management of Indian dry deciduous forests. Int j sust dev world 19(2): 155-171

Desselle SP (2005) Construction, implementation, and analysis of summated rating attitude scales. Am J Pharm Educ 69(5): 1-11

Devereux S (1992) Learning the language and counting the people in Ghana. In: Devereux S, Hoddinott J. Fieldwork in developing countries (eds) Harvester Wheatsheaf, London. pp. 43-56

Djamhuri TL (2012) The effect of incentive structure to community participation in a social forestry program on state forest land in Blora district, Indonesia. Forest Policy Econ 25: 10-18. doi:10.1016/j.forpol.2012.02.004

DWAF (Department of Water Affairs and Forestry) (2004) Key issue paper for a policy on transfers of state owned industrial plantations. http://www2.dwaf. gov.za/dwaf/cmsdocs/Elsa/Docs/Transfers/KIP\%20Policy\%20on\%20 Transfers\%202004.pdf. Accessed 20/01/2013

DWAF (Department of Water Affairs and Forestry) (2005) Forestry change programme: business process analysis report. Forestry Transfers Process Version 5.0. DWAF, Pretoria. http://www2.dwaf.gov.za/dwaf/cmsdocs/Elsa/Docs/Transfers/ Business\%20Process\%20Analysis\%20Report\%20Transfers\%202005.pdf. Accessed 20 October 2012

DWAF (Department of Water Affairs and Forestry) (2008) The National Forests Act, 1998 (Act no. 84 of 1998): draft regulations on principles, criteria and indicators of sustainable forest management. Government Gazette no 31171, Notice 792. DWAF, Pretoria. www.gov.za/documents/download.php?f=83934. Accessed 18 April 2013

Evans J (1998) Community/forestry relationships in South Africa's communal areas: tenurial challenges for community. In: Barry M, Kruger G (eds) Proceedings of the international conference on land tenure in the developing world with a focus on southern Africa, 27-29 January 1998. University of Cape Town, Cape Town. pp 264-276

Fakayode SB, Rahji MAY, Adeniyi ST (2012) Economic analysis of risks in fruit and vegetable farming in Osun state, Nigeria. Bangladesh J. Agril. Res 37(3): 473-491

FSC (2012) Revised FSC principles and criteria for forest stewardship. FSC-std-01-001 (v5-0) EN. https://ic.fsc.org/download.fsc-std-01-001-v5-0-revised-principles-and-criteria-for-foreststewardship.a-871.pdf. Accessed 4 January 2013

Gordon M, Schirmer J, Lockwood M, Vanclay F, Hanson D (2013) Being good neighbours: current practices, barriers, and opportunities for community engagement in Australian plantation forestry. Land Use Policy 34: 62- 71. doi: 10.1016/j.landusepol.2013.02.005

Gugushe NM, Grundy IM, Theron F, Chirwa PW (2008) Perceptions of forest resource use and management in two village communities in the Eastern Cape Province, South Africa. South Forests 70(3): 247-254 
Hall D (2003) The international political ecology of industrial shrimp aquaculture and industrial plantation forestry in southeast Asia. J Southeast Asian St 34(2): 251-264.

doi:10.1017/S0022463403000249

Ham C (2000a) Background study on the woodlots in the Eastern Cape Province, with special emphasis on the woodlots in the Butterworth area. Research Report No. UST 5/97. Department of Water Affairs and Forestry, Pretoria

Ham C (2000b) The importance of woodlots to local communities, small-scale entrepreneurs and indigenous forest conservation-a case study. Instruments for sustainable private sector forestry, South Africa series. International Institute for Environment and Development and CSIREnvironmentek, London and Pretoria. http://researchspace.csir.co.za/dspace/bitstream/10204/2498/1/Ham_2000.pdf?origin=publication _detail. Accessed 26 November 2011

Ham C, Chirwa P (2008) Forest resource use in southern Africa. In: Masters L, Kisiangani E (eds) Natural resources governance in southern Africa. Africa Institute of South Africa, Pretoria. pp 6794

Ham C, Theron JM (1999) Community forestry and woodlot development in South Africa: the past, present and future. South Afr Forest J 184(1): 71-79. doi:10.1080/10295925.1999.9631214

Howard M, Matikinca P, Mitchell D, Brown F, Lewis F, Mahlangu I, Msimang A, Nixon P, Radebe T (2005) Small-scale timber production in South Africa: what role in reducing poverty? Fractal Forest Africa, Fakisandla Consulting, Institute of Natural Resources, Rural Forest Management CC, South Africa, and International Institute for Environment and Development, London and Pretoria. http://pubs.iied.org/pdfs/9559IIED.pdf. Accessed 18 February 2014

ITTO (2005) Revised ITTO criteria and indicators for the sustainable management of tropical forests including reporting format. ITTO Policy Development Series No. 15. www.itto.int/direct/topics/.../topics_id=9630000\&no=1\&disp=inline. Accessed 19 September 2013

Khadka C, Vacik H (2012) Use of multi-criteria analysis (MCA) for supporting community forest management. iForest 5: 60-71. doi:10.3832/ifor0608-00

Martinez-Martin P (2010) Composite rating scales. J Neurol Sci 289(1-2): 7-11. doi:10.1016/j.jns.2009.08.013

Mattson DE (1986) Statistics: Difficult concepts, understandable explanations. Bolchazy-Carducci Publishers, Inc, Wauconda

Mayers J (2006) Poverty reduction through commercial forestry: what evidence? What prospects? The Forests Dialogue research paper, A TFD Publication No. 2. Yale University School of Forestry and Environment Studies, New Haven. http://theforestsdialogue.org/sites/default/files/mayers_poverty_publication.pdf. Accessed 10 April 2013

Monnette DR, Sullivan TJ, Dejong CR, Hilton TP (2014) Applied social research: tool for the human services, $9^{\text {th }}$ edn. Brooks/Cole Publishing, Australia

Muhammed N, Haque F, Koike M (2008) The role of participatory social forestry in the enhancementof the socio-economic condition of the rural poor: a case study of Dhaka forest division in Bangladesh. Forests, Trees and Livelihoods 19(4): 47-67. doi:10.1080/14728028.2008.9752646

Nachmias D, Frankfort-Nachmias C (1992) Research methods in the social sciences, $4^{\text {th }}$ edn. St Martin's Press, Inc, London

Obiri JAF, Lawes MJ (2002) Attitudes of coastal-forest users in Eastern Cape Province to management options arising from new South African forest policies. Environ Conserv 29(4): 519-529. doi:10.1017/S0376892902000371

Oses-Eraso N, Viladrich-Grau M (2007) On the sustainability of common property resources. J Environ Econ and Manag 53(3): 393-410. doi:10.1016/j.jeem.2006.10.006

Pokharel RK (2012) Factors influencing the management regimes of Nepal's community forestry. Forest Policy Econ 17: 13-17. doi:10.1016/j.forpol.2011.08.002 
Robertson J, Lawes MJ (2005) User perceptions of conservation and participatory management of Gxalingenwa forest, South Africa. Environ Conserv 32(1): 64-75.

doi:10.1017/S0376892905001979

Rogerson CM (2001) In search of the African miracle: debates on successful small enterprise development in Africa. Habitat Int 25: 115-142

Rohatgi VK (1984) Statistical inference. John Wiley and Sons, Inc, New York

Sarantakos S (1998) Social research, $2^{\text {nd }}$ edn. Palgrave Macmillan Limited, New York

Schirmer J, Tonts M (2003) Plantations and sustainable rural communities. Austral For 66(1): 67-74. doi:10.1080/00049158.2003.10674892

Scotcher J, Everard D (2001) Review of sustainable forest management criteria and indicators. South Afr Forest J 192(1): 1-2. doi:10.1080/20702620.2001.10434127

Shackleton C, Shackleton S (2004) The importance of non-timber forest products in rural livelihood security and as safety nets: a review of evidence from South Africa. S Afr J Sci 100: 658-664

Sikhitha ME (1999) A survey of the conservation attitudes of the rural communities surrounding Thathe forest, Northern Province. Dissertation, University of Natal

SSA (Statistics South Africa) (2014) Census 2011 community profiles

Tewari DD, Isemonger AG (1998) Joint forest management in South Gujarat, India: a case of successful community development. Community Dev J 33(1): 32-40. doi: 10.1093/cdj/33.1.32

Thoms CA (2008) Community control of resources and the challenges of improving local livelihoods: a critical examination of community forestry in Nepal. Geoforum 39(3): 1452-1465. doi:10.1016/j.geoforum.2008.01.006

UN (United Nations) (2008). Non-legally binding instrument on all types of forests. UN Resolution A/RES/62/98. http://www.un.org/en/ga/62/resolutions.shtml. Accessed 8 July 2015

Wolfslehner B, Vacik H, Lexer MJ (2005) Application of the analytic network process in multi-criteria analysis of sustainable forest management. Forest Ecol Manag 207(1-2): 157-170. doi:10.1016/j.foreco.2004.10.025 